\title{
SPEAKING STRATEGIES USED BY INDONESIAN TERTIARY STUDENTS
}

\author{
Wawa Puja Prabawa \\ STKIP Pasundan Cimahi, Indonesia \\ Email: wawapuja@gmail.com
}

APA Citation: Prabawa, W. P. (2016). Speaking strategies used by Indonesian tertiary students. English Review, 4(2), 231-242

\begin{abstract}
Speaking is considered to be difficult thing, moreover English as a foreign language. Students' performance depends on their personalities. Students who have low participation in speaking activity in the classroom lose their opportunity to practice their speaking skill which may cause poor speaking skill and achievement. However, some of students are active in speaking activity in the classroom that leads them to have good skill and achievement in speaking. This study attempts to reveal: (1) speaking strategies used by Indonesian tertiary students in terms of speaking English and strategies to improve their speaking ability, and (2) to identify speaking strategies mostly used by the students when they speak English and improve their speaking ability. This study is a descriptive research since its purpose is to describe the Indonesian tertiary students' learning strategies in learning speaking English. The data from 15 tertiary students, who have good performance and achievement in speaking, from one of schools of higher education in Cimahi were collected using a 21 items questionnaire of a modified version of Strategy Inventory Language Learning (SILL) and 5 items interview questions. The result of the study revealed that some speaking strategies are used in terms of speaking English and improve speaking ability, namely cognitive, metacognitive and compensation strategy. In the type of speaking strategy that mostly used by the student in terms of speaking English is compensation strategy, while cognitive strategy was indicated as the mostly speaking strategies used by the Indonesian tertiary students in improving their speaking ability. Considering to the study conducted, it is recommended to students that they should know what strategies that appropriate and can help them in learning speaking English. The students should be able to choose strategies they need in learning and analyze which strategies that give better effect on their own learning.
\end{abstract}

Keywords: Speaking, strategy, speaking strategy, tertiary students

\section{INTRODUCTION}

People usually learn English because for some reasons, in some ways, they want to be able to communicate in English (Edge, 1993, p. 17). Furthermore, he points out that people are motivated to learn English as the language of International language (p. 18). In Indonesia, English becomes one of the important subjects to be mastered by students at school, start from

kindergarten up to university students. Language means something spoken. People usually speak or share their opinion with one another by using it. By mastering speaking, they can carry out conversation with others, give ideas and change the information with interlocutors (Fajariyah, 2009, p. 14). It means that speaking has a role in the language skill. 
Speaking is an activity used by someone to communicate with other(s). It takes place everywhere and has become part of our daily activities. When someone speaks, he or she interacts and uses the language to express his or her ideas, feeling and thought. He or she also shares information with other(s) through communication. Speaking is one of the main purposes of language learning in that it is an ability to transfer some ideas to other people clearly and correctly. In other words, people can communicate their ideas well to other people (Argawati, 2014, p. 76). Communication is important. People need to talk each other, share their ideas, feeling their expressions and thoughts, and they need to understand each other. That becomes the reason why people need to speak.

Among the four language skills, learners consider speaking as the most difficult one since it needs great courage as well as preparation to produce the language. Their personalities play a large role in determining how quickly and how correctly they will accomplish this skill. Those who are risk-takers unafraid of making mistakes will generally be more talkative, but they do not realize with the errors they make. Meanwhile, the conservative, shy students may take a long time to speak confidently, but when they do, they will make fewer errors and be proud of their English ability. Learners will think about which one is better, to talk much with many errors or to think more with better result. It can be answered when the aims of speaking is clearly stated, that is to build meaningful communication. In this case, to encourage learners to talk as much as possible to convey the messages of communication is more important rather than to let them think about grammar rules they use (Malihah, 2010, p. 86).
In addition, Malihah $(2010$, p. 87) suggests that there is a phenomenon today that students are sometimes not motivated to talk because they are lack involvement in the topic. Besides, many students have to overcome psychological constraints before they are prepared to speak in the foreign language. Some students feel uneasy when they have to speak in the classroom situation because there is always an audience. A few prefer not to speak at all and deny opportunities for practice. They feel so anxious in practicing their speaking skill in foreign language. For instance, some students have low participation in speaking activity in the classroom. It means that they lose their opportunity to practice their speaking skill which may cause poor speaking skill (Rahmadeni, Amri, and Adnan, 2013, p. 413).

It is a common thing facing difficulties in learning speaking English. The most important thing is how the students deal with such problem. Cohen (1998, p. 66) in Rahmadeni, Amri and Adnan (2013, p. 413) states that language learning will be easier if the students become more aware of possible strategies that can be selected during learning and using language. He also believes that the students' language skill can be improved by themselves when they become more aware of what helps them to learn the language they are studying most efficiently.

Every student has their own learning strategies in studying English. It can be seen from the successful students rather than method or techniques of teaching. After observing and teaching some students in one of Schools of Higher Education in Cimahi majoring in English Education Study Program, some of them have low participation in speaking activity in the classroom. On one hand, the students' less participation 
in the classroom caused the students' low achievement in speaking. On the other hand, some of the students were active in speaking activity in the classroom. They also have good achievement in speaking.

Understanding speaking depends on the students in learning speaking. Considering to the issue, the major purposes of this study are: 1) to investigate speaking strategies used by the Indonesian EFL tertiary students in terms of they speak English and improve their speaking ability, and 2) to identify the mostly speaking strategies used by the students in terms of speaking English and improve their speaking ability.

Listening to English songs, watching English movie, practicing with friends, and many more are some strategies that can be used by the students to make their speaking becomes more fluent. Some strategies can be chosen by the students based on their needs. The students' intention use the strategies in learning is to help them in learning process, especially in speaking.

O'Malley (1990, p. 188) explains good learners are aware of the learning process and themselves as learners, seek to control their own learning through the use of appropriate learning strategy. Styles are general characteristics that differentiate one individual from another and learning strategies are the special achieve or behaviours that individual use to help them comprehended, learn or retain new information.

Some experts have been tried to define learning strategies. Wahyuni (2013, p. 4) provides some definitions from them that there is no consensus about the definition of learning strategies. Researchers (for example Brown, 2000; Cohen, 1990; Green and Oxford, 1995; Griffiths, 2008; O'Malley and Chamot, 1990; Oxford, 1990; Rubin,
1975; Stern, 1992; Wenden and Rubin, 1987) define language learning strategies in slightly different ways, causing a debate about whether they are physical or mental, conscious or subconscious, and problem-or goal-triggered.

O'Malley (1985, p.23) provides broad definition of language learning strategies as "any set of operations or steps used by a learner that will facilitate the acquisition, storage, retrieval or use of information." Griffiths (2008) defines learning strategies as "activities consciously chosen by learners for the purpose of regulating their own language learning (p.87)." Besides, Nunan (1999, p. 171) defines "learning strategies are the mental and communicative procedures learners use in order to learn and use language."

However, to provide a working definition for this study, I have adopted Oxford's definition. Oxford (1990, p. 1) defines learning strategies as step used by the students to improve their own learning. Furthermore, she attempts to classify learning strategies into six groups: memory strategies (which relate to how students remember language), cognitive strategies (which relate to how students think about their learning), compensation strategies (which enable students to make up for limited knowledge), metacognitive strategies (relating to how students manage their own learning), affective strategies (relating to students' feelings) and social strategies (which involve learning by interaction with others). This theory becomes the theoretical base of the study.

In the area of speaking skill, some studies use theories of learning strategies as their theoretical bases. Lopez (2011) for example, showed her result that students tend to select strategies according to their level of language proficiency. In Indonesian context, 
Rahmadeni, Amri \& Adnan (2013) reported on their study that students prefer to use metacognitive strategies as their strategy preferences in speaking English. Besides, Mistar and Umamah (2014) found that gender provided significant effects on the intensity of use of six types of strategies of learning skill with female learners reporting higher intensity of use. A further analysis found that four strategy types - interactionalmaintenance, self-improvement, compensation, and memory strategies-greatly contribute to the speaking proficiency.

In addition, Wahyuni (2013) reported that the correlation between overall speaking strategy use and speaking proficiency is not significant, though positive. However, the effect of gender on strategy preference is found significant on affective strategies. Whereas, Moriam (2005) who investigated Japanese and Bangladeshi university students, found that Bangladeshi employ cognitive and interpersonal strategies more than Japanese, and that gender difference of both groups provides insignificant effect of the use of speaking strategies, except that cognitive strategies used by Japanese females are found to be higher than those by the male.

Meanwhile, Larenas (2011), investigated speaking strategies used by eight and twelfth graders, found that $8^{\text {th }}$ graders claim to have broader knowledge of speaking strategies than $12^{\text {th }}$ year secondary students, and the knowledge of speaking strategies of elementary and secondary school students does not vary depending on the type of school: public, semi-public and/or private.

Based on the explanation above, the present study was conducted in order to see kinds of learning strategies used by the students of English Education Study Program in one of School of Higher Education in Cimahi. This study analyzed the learning strategies used by the students in learning speaking English.

The study covers only on speaking strategies used by the English Education Study Program students in terms of at the time they speak English and improve their speaking ability. The subject of the study is limited to the students who have high proficiency in speaking and it is proven by their scores who always get $\mathrm{A}$ in speaking course. A number of studies have been conducted in the area of Language Learning Strategies (LLS) in particular of speaking strategies. To fill this gap, this study intends to explore speaking strategies used by Indonesian tertiary students. Therefore, the present study seeks answers to the following questions:

1. What kinds of speaking strategies used by Indonesian tertiary students in terms of they speak English and improve their speaking ability?

2. What kinds of speaking strategies mostly used by Indonesian tertiary students in terms of they speak English and improve their speaking ability?

By knowing the students learning strategies, especially in speaking strategies, it is expected that this research will give valuable contribution for the teacher to find teaching strategies that are suitable to the students' learning strategies. It can also increase students' knowledge about learning strategies in speaking. Moreover, it can be adopted by students who want to improve their speaking ability in learning speaking English. It is expected that students can speak more effectively after applying those kinds of strategies. Furthermore, it gives 
additional information to students to find the most suitable strategy to improve their speaking skill.

To avoid misconception and misunderstanding, several terms are clarified. Those are:

1. Speaking is an act to express idea, feelings, and thought orally. It is also called oral communication. It is an act that is done naturally by people in their life. They have a freedom to express what they want to say. To communicate becomes the main goal of speaking.

2. Strategies are specific actions, behaviours, steps or techniques that students (often intentionally) use to improve their progress in developing L2 skills. These strategies can facilitate the internalization, storage, retrieval or use of the new language. Strategies are tools for the self-directed involvement necessary for developing communicative ability (Oxford, 1992, p. 15).

3. Tertiary means education after Secondary level. Primary and Secondary level are compulsory (in most countries) whereas Tertiary is not. Tertiary means any form of higher education, e.g. college, university. Thus, tertiary students refer to students who take higher education in college or university.

Over the past decade, the effort to explore the relationship of the use of language learning strategies with other variables such as motivation, gender, cultural background, type of task, age, level of L2 and learning style has been given tremendous importance (Oxford, 1993) in Moriam (2005, p. 48).

There are some learning strategies that can be applied by the students in learning. Oxford (1990) proposes two major groups of learning strategies: direct strategies and indirect strategies. Direct strategies consist of memory strategies, cognitive strategies, and compensation strategies.

Meanwhile, indirect strategies are classified into metacognitive strategies, affective strategies, and social strategies. Based on the two groups of learning strategies, there are some learning strategies for learning speaking. They can be seen in the following table 1 .

Table 1. Language Learning Strategies for Speaking Classified by Oxford (1990)

\begin{tabular}{|c|c|c|}
\hline $\begin{array}{l}\text { Groups of } \\
\text { Strategies }\end{array}$ & $\begin{array}{l}\text { Types of } \\
\text { Learning } \\
\text { Strategies }\end{array}$ & Learning Strategies for Speaking \\
\hline \multirow{7}{*}{$\begin{array}{l}\text { Direct } \\
\text { Strategies }\end{array}$} & Memory & a. $\quad$ Creating mental linkages (Placing new words into a context) \\
\hline & Strategies & $\begin{array}{l}\text { b. Applying images and sounds (Representing sounds) } \\
\text { c. Reviewing well (Structured reviewing) } \\
\text { d. Employing action (Using memory strategies for retrieval is memory } \\
\text { strategies under using mechanical techniques) }\end{array}$ \\
\hline & $\begin{array}{l}\text { Cognitive } \\
\text { Strategies }\end{array}$ & $\begin{array}{l}\text { a. Practicing (repetition, formally practicing with sounds and writing } \\
\text { systems, recognizing and using formulas and patterns, recombining, } \\
\text { practicing naturalistically) }\end{array}$ \\
\hline & & $\begin{array}{l}\text { b. Receiving and sending messages (Using resources for receiving and } \\
\text { sending messages) }\end{array}$ \\
\hline & & $\begin{array}{l}\text { c. Analyzing and reasoning (Reasoning deductively, translating, } \\
\text { transferring) }\end{array}$ \\
\hline & $\begin{array}{l}\text { Compensation } \\
\text { Strategies }\end{array}$ & $\begin{array}{l}\text { a. Switching to the mother tongue (using the mother tongue for an } \\
\text { expression without translating it) }\end{array}$ \\
\hline & & $\begin{array}{l}\text { b. Getting help (asking someone for help in a conversation by hesitating } \\
\text { or explicitly asking for the missing expression) }\end{array}$ \\
\hline
\end{tabular}




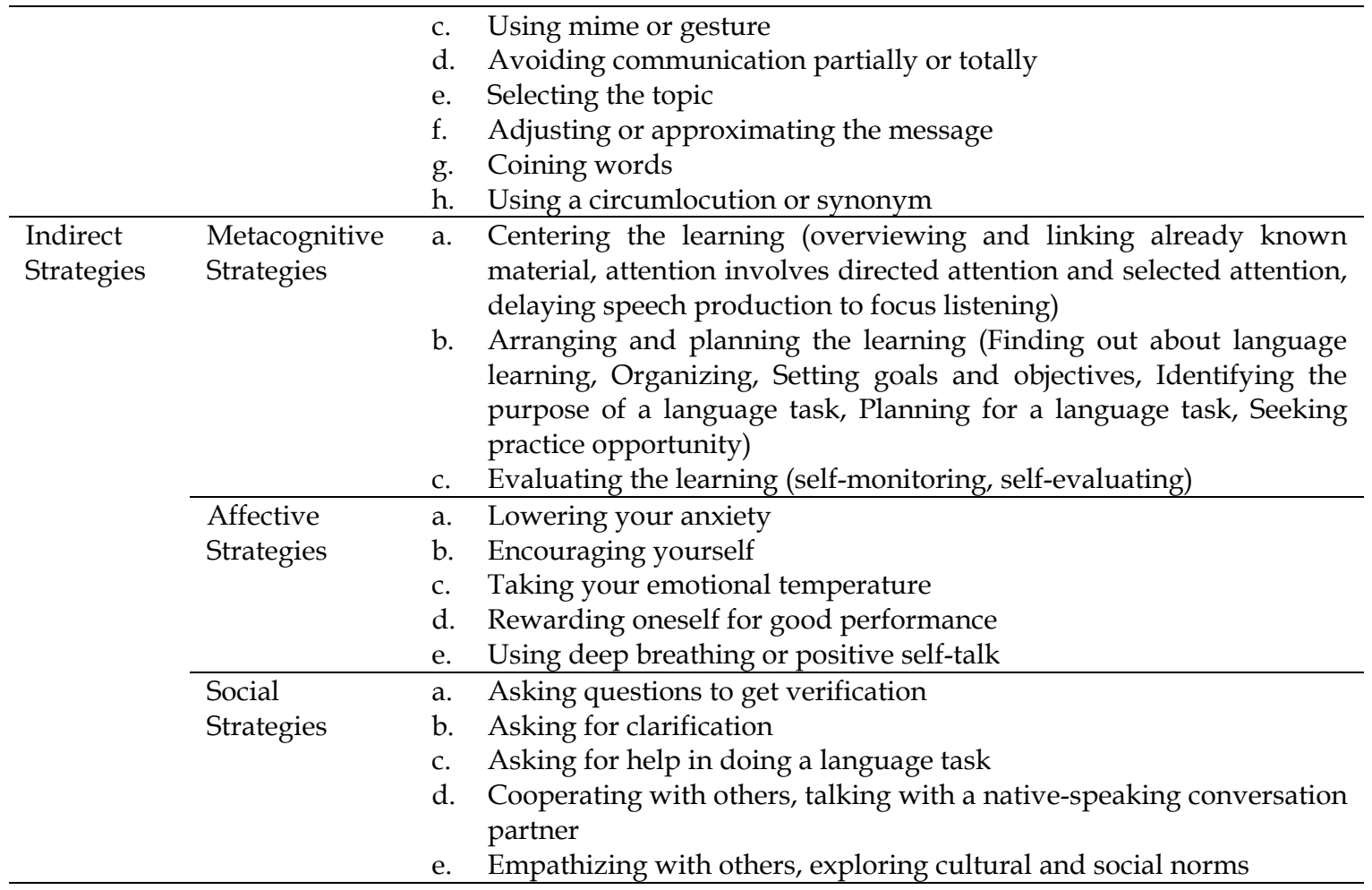

These strategies can be specified as follows: 1) Memory strategies for remembering and retrieving new information. 2) Cognitive strategies for understanding and producing the language. 3) Compensation strategies for using the language despite lack of knowledge. 4) Metacognitive strategies for coordinating the learning process. 5) Affective strategies for regulating emotions. 6) Social strategies for learning with others (Oxford, 1990, p. 14-15).

Furthermore, Nakatani (2006) groups speaking strategies into seven different types which are described as follows:

- Strategy type 1: Fluency-oriented strategy; this strategy is seen when students pay attention to aspects like rhythm, intonation, pronunciation and speech clarity in order to improve listeners' attention.

- Strategy type 2: Negotiation for meaning while speaking; this strategy is related to the speaker's attempts to negotiate with the listener. To keep and maintain their interaction and avoid breakdowns while communicating, they both modified the message by giving examples and repeating the speech to figure out what they really wanted to say.

- Strategy type 3: Accuracy-oriented strategy; it is associated with the desire to speak English with some accuracy. Learners pay attention to the form of their speech and look for grammatical accuracy; therefore, they correct what they are saying by noticing their own mistakes.

- Strategy type 4: Message reduction and alteration strategy; it is closely connected with the reduction and simplification of the message by using similar expressions in order to avoid breakdowns.

- Strategy type 5: Non-verbal strategy while speaking; this strategy is directly linked to the use of body language. Learners use eye contact, gestures and 
facial expressions to achieve communication.

- Strategy type 6: Message abandonment strategy; it is associated with the abandonment of the message in ESL communication. Learners have a tendency to give up their endeavor to communicate when they face difficulties carrying out their message.

- Strategy type 7: Attempt to think in English strategy; this strategy is useful for learners who think in the second language during their speech. Learners tend to think in English and avoid thinking in their native language.

O'Malley and Chamot (1990) reveal their study that more effective (higher proficiency students generally use a greater variety of strategies and use them in ways that help the student complete language tasks more successfully; conversely, less effective (low proficiency) students not only have fewer strategies but also frequently use strategies that are inappropriate to the task or that do not lead to successful task completion. A study conducted by Gharbavi and Mousavi (2012) show that the higher the level the learners are at, the greater the number of strategies they use.

Kustati (2003), in her research, found that practicing naturally and using circumlocution and synonym are the highest intensity of speaking related Language Learning Strategies (LLS) used by the students in speaking. In line with that, Liu (2004) revealed his study that students of the Chinese technological institute English majors used metacognitive strategies as the most frequently used strategies in speaking. Furthermore, Volya (2009) reported that the strategies used were speaking with friends, speaking with English teacher, trying to find English speaker, and talking to themselves in English, taking
English course, making dialogues, listening English music and watching English movie, those strategies were perceived, believed, regarded, though and considered differently by the students.

\section{METHODS}

This study was a descriptive research since its purpose was to describe the Indonesian tertiary students' learning strategies in learning speaking English. Descriptive research is helpful for examining a variety of educational problems and issue (Gay, 2009, p. 275). In this research, the population was students of English Education Study Program of one of Schools of Higher Education in Cimahi. Meanwhile, the sample of the research was 15 students consisting of students who have high performance in speaking.

The research instruments were questionnaire and interview. The questionnaire used in this research was a modified version of Strategy Inventory for Language Learning (SILL) developed by Oxford $(1990,293-300)$ consisted of 21 items. After administering the questionnaire to the students, interview was conducted to support and gain the data. The results of interview would strengthen the data gained through questionnaire. The interview used openended question to gain information about the speaking strategies used by the students.

The data, strategy that has the highest score, was indicated as a strategy mostly used by a student. Then, the results were analyzed by using simple scaling percentage to see the strategy which was mostly used by all the students. The percentage formula is as follow: 


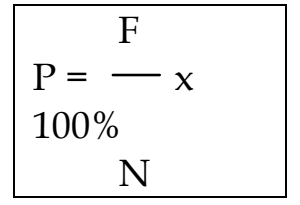

Where:

$\mathrm{P}$ : Percentage

F : Frequency of answer (total respondents who answer an item)

$\mathrm{N}$ : Total respondents

After classifying, the data was interpreted to get general conclusion. The strategy that has the highest score was indicated as a strategy mostly used by the students.

\section{RESULTS AND DISCUSSION}

Question 1: What kinds of speaking strategies used by Indonesian tertiary students in terms of they speak English and improve their speaking ability?

The following table are the percentage for questionnaire results. And it is supported by the interview result.

Table 2. Average Percentage of Speaking Strategies Used by Indonesian Tertiary Students

\begin{tabular}{|c|c|c|c|}
\hline \multicolumn{2}{|c|}{ Types of Strategies } & Frequency & Percentage \\
\hline \multirow[t]{2}{*}{ In terms of Speaking English } & Compensation Strategy & 14 & $93.33 \%$ \\
\hline & Metacognitive Strategy & 1 & $6.67 \%$ \\
\hline Improving Speaking Ability & Cognitive Strategy & 13 & $86.67 \%$ \\
\hline & Metacognitive Strategy & 2 & $13.33 \%$ \\
\hline
\end{tabular}

a. In terms of Speaking English

From the table 2 above, it is shown that in terms of speaking English, there were two strategies used by the students: compensation and metacognitive strategy. 10 students used circumlocution and synonym, 3 students used gesture, and 1 student used switching to mother tongue as their compensation strategy.

Meanwhile, 1 student used metacognitive strategy by applying evaluating and learning, making correction of himself when he makes an error.

b. Improving Speaking Ability From the table 2 above, it can be seen that there were two kinds of strategies used by the students in improving their speaking ability, namely cognitive and metacognitive strategy. There were 12 students who like watching films or TV programs in English and there was 1 student who read newspaper and books in order to learn new structure and words as cognitive strategy. While, there were 2 students who repeat after listening to radio, recordings or music as metacognitive strategy.

Question 2: What kinds of speaking strategies mostly used by Indonesian tertiary students in terms of they speak English and improve their speaking ability? 


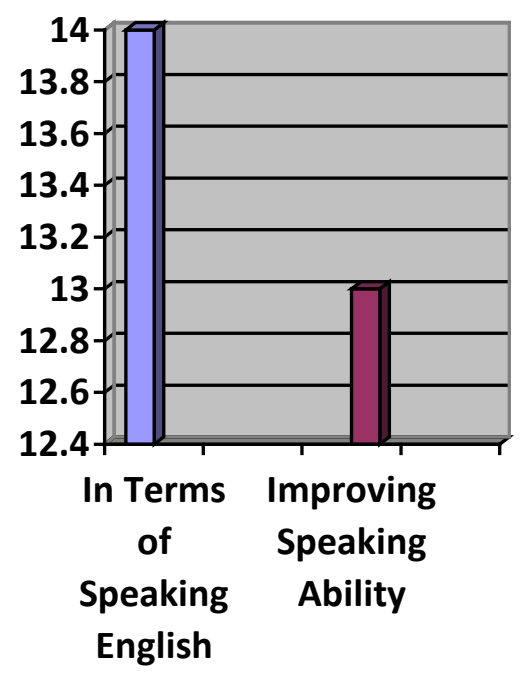

\begin{tabular}{|c|}
\hline Compensation \\
Strategy \\
$\square$ Cognitive \\
Strategy
\end{tabular}

Diagram 1. Speaking Strategies Mostly Used by Indonesian Tertiary Students

From the diagram 1 above, there were 14 students or about $93.33 \%$ used compensation strategy as their speaking strategy when they speak English. They mostly used synonym to explain the word in English. Al Buainain (2010) states that compensation strategies enable the students to make up for missing knowledge in the process of comprehending or producing the target language. Meanwhile, there were 13 students or about $86.67 \%$ used cognitive strategy as their speaking strategy to improve their speaking ability. They mostly used watch films or TV programs in English because it can entertain them, it does not make boring, it makes enjoyment and fun so they are interested in learning English, especially in learning speaking. As what Oxford (1990, p. 43) says that cognitive learning strategy is essential in learning a language.

Therefore, it can be assured that the result of the students' speaking ability will rise due to the application of the cognitive strategy.

\section{CONCLUSION}

Based on the research findings, it was found that there are some strategies used by Indonesian tertiary students when they speak English and improve their speaking ability, namely cognitive, metacognitive and compensation strategy. In the type of speaking strategy that mostly used by the student in terms of speaking English is compensation strategy, while cognitive strategy was indicated as the mostly speaking strategies used by the Indonesian tertiary students in improving their speaking ability.

Considering to the research conducted, there are some recommendations that can be proposed to the teachers and students. It is recommended for the teacher to find the language learning strategies, especially speaking strategies, of their students and help them balance the strategies used by the students based on the students' needs and preferences. The teacher should adapt the teaching strategies with the students learning strategies to enhance students' achievement in 
learning speaking. For the students itself, they should know what strategies that appropriate and can help them in learning speaking English. The students should be able to choose strategies they need in learning and analyze which strategies which give better effect on their own learning.

\section{REFERENCES}

Al-Buainain, H. (2010). Language learning strategies employed by English majors at Qatar university: Question and queries. Asiatic: IIUM Journal of English Language and Literature, Volume 4, Number 2, December 2010, p. 92-120. Retrieved from http://www.myjurnal.my/public/arti cle-view.php?id=14934 on December 29th, 2015

Argawati, N. O. (2014). Improving students' speaking skill using group discussion; Experimental study on the first grade students of senior high school. ELTIN Journal, 2(II), p. 74-81.

Edge, J. (1993). Essentials of English language teaching. New York: Longman

Fajariyah, D. N. (2009). Improving students speaking proficiency using games; A classroom action research on the eighth grade students of SMP Negeri 2 Baki Sukoharjo 2008/2009 academic year. Surakarta: Sebelas Maret University. Thesis.

Gay, L. R. (2009). Educational research. New Jersey: Pearson Education Inc.

Gharbavi, A., \& Mousavi, S. A. (2012). Do language proficiency levels correspond to language learning strategy adoption? English Language Teaching, 5(7), 110-122.

Griffiths, C. (2008). Lessons from good language learners. Cambridge: Cambridge University Press.

Kustati, M. (2003). Students speaking-related language learning strategies in their speaking ability. Padang: Padang State University.

Larenas, C. D. (2011). Exploring knowledge of English speaking strategies in 8th and 12th graders. PROFILE, 13(2), $p$. 85-97.

Liu, D. (2004). EFL proficiency, gender and language learning strategy use among a group of Chinese technological institute English majors. Retrieved from http:/ / www.ecls.ncl.ac.uk/ publish/Volume

1/Dongyue/Dongyue.htm.pdf on December 29th, 2015.

López, M. M. (2011). Speaking strategies used by BA ELT students in public universities in Mexico. MEXTESOL Journal, 35(1), 1-22.

Malihah, Noor. (2010). The effectiveness of speaking instruction through taskbased language teaching. REGISTER, 3(1), p. 85-101.

Mistar, J., Zuhairi, A., \& Umamah, A. (2014). Strategies of learning speaking skill by senior high school EFL learners in Indonesia. Paper presented at the 10th International TESOL Conference, Manila.

Moriam, Q. M. (2005). Speaking strategy use by the EFL students in Japan and Bangladesh. Journal of International Development and Cooperation, 12(1), 4761.

Nakatani, Y. (2006). Developing an oral communication strategy inventory. The Modern Language Journal, 90(2), 151-168.

Nunan, D. (1999). Language teaching methodology: A textbook for teachers. Kuala Lumpur: Pearson Education.

O' Malley, J. M. \& Chamot, A. U. (1990). Learning strategies in second language acquisition. Cambridge: Cambridge University Press.

Oxford, R. L. (1990). Language learning strategies: What every teacher should know. New York: Newbury House.

Rahmadeni, Y., Amri, Z., \& Adnan, A. (2013). Junior high school sudents' learning strategies and their achievement in speaking: A case study at SMP Negeri 3 Padang Panjang. Journal of English Language Teaching, 2(1), p. 412-422.

Wahyuni, S. (2013). L2 speaking strategies employed by Indonesian EFL tertiary 
ENGLISH REVIEW: Journal of English Education Vol. 4, Issue 2, June 2016

students across proficiency and gender. (Ph.D thesis, University of Canberra, Australia).

Volya, Duti. (2009). Students' speaking strategies and teachers' teaching
ISSN 2301-7554

https://journal.uniku.ac.id/index.php/ERJEE

speaking strategies at senior high school in Kerinci district. Retrieved from http:/ /jurnal.pdii.lipi.go.id/ admin/ jurnal/ 96jan098790.pdf on December 29th, 2015. 
